UDC 539.2

V.O. Zotyeyev

Odessa National Polytechnic University, 1 Shevchenko Ave., Odessa, Ukraine, 65044

\title{
AGING AND LIFETIME MANAGEMENT OF SHIPBOARD GAS TURBINE UNITS
}

\begin{abstract}
B.O. Зотєєв. Керування ресурсом суднових газотурбіних агрегатів. Розглянуто проблеми, які відносяться до оцінки надійності суднового газотурбіного агрегату експертними методами та, як внаслідок, знаходженню ступені ризику, який супроводжує дозвіл судну на вихід у рейс. Крім того, для продовження терміну служби компонентів газових турбін були запропоновані захисні ерозиційностіцкого покриття і демпфирующие покриття для лопаток газової турбіни.

Ключові слова: газотурбіний агрегат, експертні методи оцінки надійності, подовження ресурсу, ерозійностійки та демпфуючі покриття
\end{abstract}

V.O. Zotyeyev. Aging and lifetime management of shipboard gas turbine units. There the problems concerning estimation of the reliability of the ship's gas turbine unit by expert methods, as well as finding the level of risk, which accompanies the ship's permission to sail were considered in the work. In addition, to extend the timelife of gas turbine components the protective erosion coatings and damping coatings for gas turbine blades were proposed.

Keywords: gas turbine units, expert methods to evaluate reliability, extended lifetime, erosion-resistant and damping coatings

Introduction. Safety of sailing is provided mainly by reliable operation of main propulsion system. As shown by the practice of recent years, reliable operation of the ship propulsion system is particularly important for navy and passenger vessels. That is why usually two types of main engines are used. Diesel and gas turbine unit (GTU) are installed to provide the ability of movement in case one of the engines fails.

The main advantage of GTU is significant ratio "power to weight". Modern gas turbine power unit has to operate without failures for a long period of time (around 10 thousand running hours). In particular, during sailing, the gas turbine power unit must guarantee the movement of the ship in any circumstances and weather conditions.

At the moment, the questions to do a changeover to technical condition based repair (CBR) of main power generation equipment including shipboard power unit are discussed. At this point, to optimize a turnaround period the methods, based on expert approach, are becoming widespread.

Expert method approach. The project data is used as an original material to perform expert analysis of equipment reliability and the data, obtained from personnel repairing this equipment. The following information is taken into account: conditions of operation, statistic data about failures and defects of equipment, drawings and specification of equipment, system functions and possible types of failures. It means that in real operation, as well as in terms of NPS, all solutions and facilities known to the science to improve the safety of equipment are involved as much as possible. These conditions force to go outside the framework of possibility methods and use additional tools to collect data and take decisions.

We consider that in this situation the methods designed by L.A. Zade [1, 5], I. Mamdani [2, 4], are more effective and reliable than others. Reliable operation of NPS power equipment has been analyzed by us using such methods [3].

The problems, related to the gas turbine power plant current reliability evaluation with expert methods and consequently risk grade determination, following the ship's permission to sail are considered in this work. Tasks, related to the reliability evaluation and a risk of incident coupled with it, are typical prediction tasks. Condition prediction of a large system assumes presence of uncertainty in operation of different subsystems. Selection of method to study such a kind of system comes to a point which of modern apparatus will be accepted to uncover this uncertainty. 
We have considered the problems related to the gas turbine power plant current reliability evaluation applying expert methods and risk grade determination following ship's permission to sail. In our opinion, tasks linked to the reliability evaluation and risks of failure are typical tasks of forecasting [6].

Results of investigation. To perform the current reliability expert evaluation and malfunction prediction, it is expedient to distinguish conditional subsystems that serve the system "compressor gas turbine - generator (main driven shaft)"of power unit.

Such subsystems at this point can be:

- subsystem of combined rotor dynamics (compressor - GTU - shaft);

- subsystem of the gas vortex flow that is affected by compression and expansion;

- subsystem of fuel treatment supply and ignition;

- subsystem of lubricating oil supply;

- subsystem of preparation and air supply into combustion chamber;

- subsystem of washing and purging of flow part;

- subsystem of GTU start from cold condition;

- subsystem of ignition suppression outside combustion chamber.

To perform a transition to the composition of fuzzy model of risk evaluation, four linguistic variables (LV) are used at the input and one LV at the output. To find the risk grade value, the data must be entered into the input blocks and then be processed with FIS algorithm.

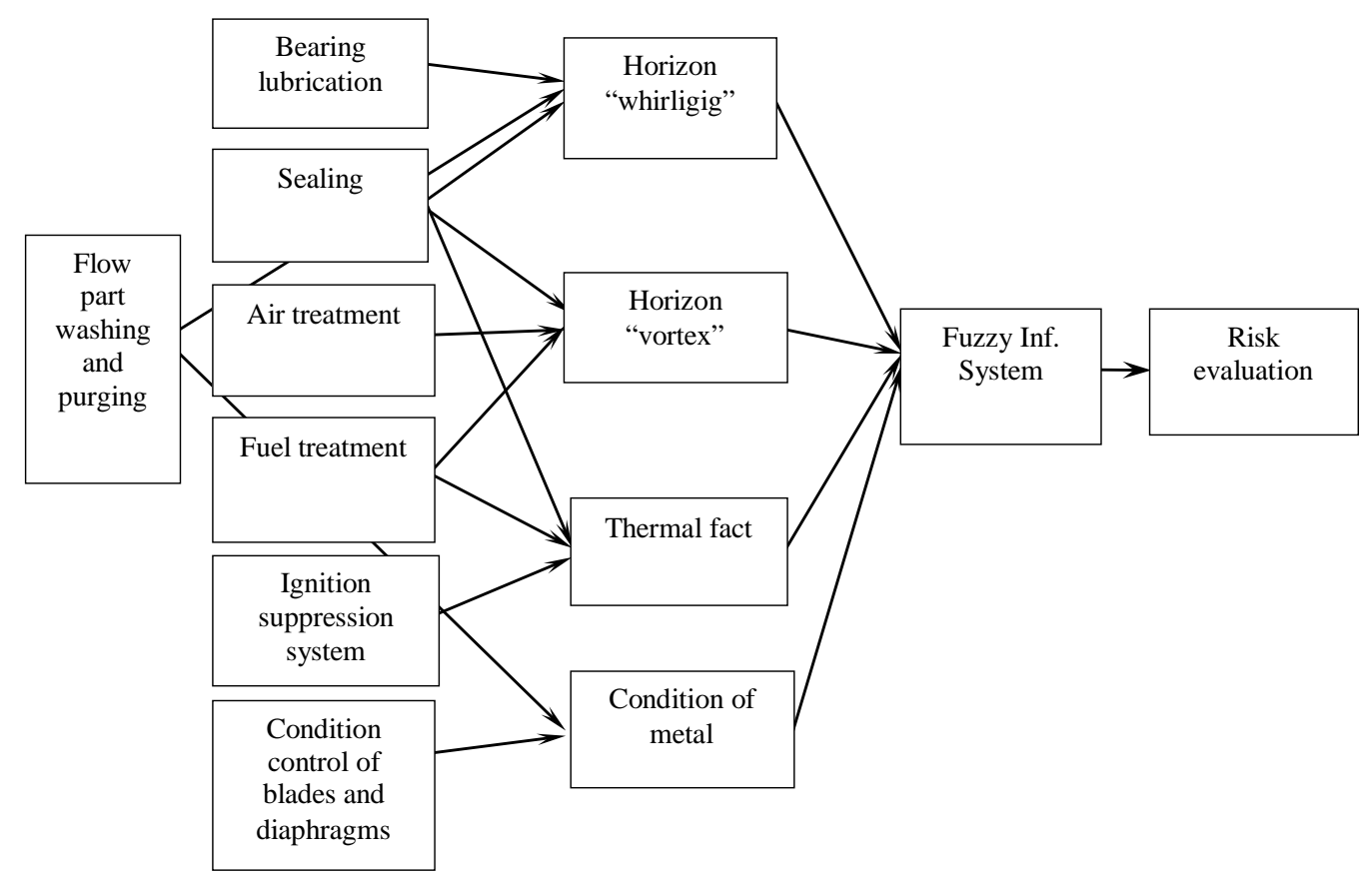

Fig. 1. General expert approach to evaluate risk grade of GTU failure

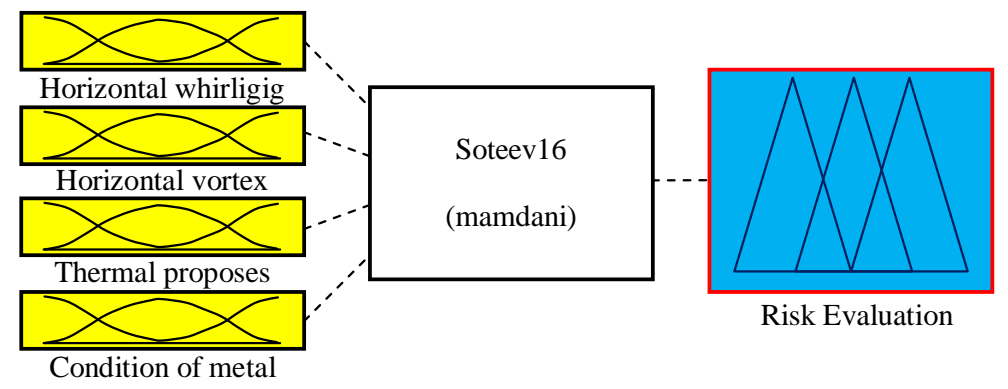

Fig. 2. A fuzzy system scheme to evaluate risk grade of GTU failure before vessel giving permission to sail 
Discussion. Taking a closer look on the influence of different subsystems of GTU that effect reliable operation of the whole unit, we have distinguished a subsystem "condition of metal" as the most critical for the system operation. It is known that main parts of GTU, blades in particular, during operation are subjected to high loads that significantly reduce their lifetime. Erosion wear and the loads creating significant vibrations during a start of the unit are the causes of these damages. In our opinion, to reduce the effect from this kind of loads it is expedient to use protective coatings. To increase resistance to erosion damages, the coating, based on zirconium dioxide can be used. Author participated in work to study crystal lattice dynamics of such compounds [7]. Obtained results allowed make a conclusion of high thermo-physical properties of these solid solutions. In its turn, the application of protective $\mathrm{Mn}-\mathrm{Cu}$ based coatings will significantly reduce the damage developed during launching loads.

\section{Conclusions.}

Using expert methods reliable operation of GTU as a "large system" can be evaluated with sufficient accuracy.

During operation the risk of GTU failure can be minimized when use protective coatings (erosion resistant and damping) on the most critical parts of the unit - gas turbine blades.

\section{Література}

1. Заде, Л.А. Понятие лингвистической переменной и его применение к принятию приближенных решений / Л.А. Заде. - М.: Мир, 1976.- 165 с.

2. Mamdani, E.H. Fuzzy logic Controller for dynamic Plant / E.H. Mamdani, S.A. Assilian. - Int. Journal of Man-Machine Study. - 1975. - V.7 - P. 1 -13.

3. Харабет, А.Н. Применение теории возможностей для определения надежности энергетического оборудования АЭС. Кластерный анализ / А.Н. Харабет, О.Е. Зотеев, О.А. Чулкин // Ядерна Енергетика та Довкілля. - 2013. - № 2, С. 63 - 69.

4. Месарович, М. Теория иерархических многоуровневых систем: Пер. с англ./ М. Месарович, Д. Мако, И. Такахара. -М.: Мир, 1973. - 344 с.

5. Беллман Р. Принятие решений в расплывчатых условиях / Беллман Р.,Заде Л. // Вопросы анализа и процедуры принятия решений; сб.переводов. - М.: Мир, 1976, С. 172 - 215.

6. Проталинский, О.М. Определение показателей возникновения аварийных ситуаций в морских технических системах / Проталинский О.М., Немчинов Д.В.// Вестник АГТУ. - 2008. - № 5.C. $104-109$.

7. Структура и динамика кристаллической решетки твердых растворов на основе диоксида циркония / А.А. Василькевич, В.О. Зотеев, О.Е. Зотеев, А.В. Коц, В.И. Слисенко // Повышение безопасности и эффективности атомной энергетики: Сборник докладов IV международной научнопрактической конференции (30 сентября - 03 октября 2014 года). - Одесса, 2012. - С. 290 - 295

\section{Reference}

1. Zade, L.A. (1976). The concept of a linguistic variable and its application to the adoption of approximate solutions. Moscow: Mir.

2. Mamdani, E.H., \& Assilian, S.A. (1975). Fuzzy logic Controller for dynamic Plant. Int. Journal of ManMachine Study, Vol. 7, 1-13.

3. Kharabet, A.N., Zotyeyev, O.Ye., Chulkin, O.A. (2013). Primeneniye teorii vozmozhnostey dlya opredeleniya nadezhnosti energeticheskogo oborudovaniya AES. Klasternyy analiz [Application of the theory of possibilities for determining the reliability of nuclear power equipment. Cluster analysis]. Yaderna Yenergetika ta Dovkíllya - Nuclear Energy and Dovkill, 2, 63-69.

4. Mesarovich M., Mako D.,\& Takakhara I. (1973) Teoriya iyerarkhicheskikh mnogourovnevykh sistem: Per. s angl. [Theory of hierarchical multi-level systems], Moscow: Mir.

5. Bellman, R.,\& Zade, L. (1976). Prinyatiye resheniy v rasplyvchatykh usloviyakh [Decision-making under vague conditions]. Voprosy analiza i protsedury prinyatiya resheniy; sb.perevodov - Analysis questions and decision-making procedures; sbr.perevodov, Moscow: Mir. 
6. Protalinskiy O.M., \& Nemchinov D.V. (2008). Opredeleniye pokazateley vozniknoveniya avariynykh situatsiy v morskikh tekhnicheskikh sistemakh. [Determination of indicators of emergencies in marine technical systems]. Vestnik AGTU - Vestnik ASTU, 5,104-109.

7. Vasilkevich, A. A., Zotyeyev, V.O., Zotyeyev, O.E., Kots, A.V., \& Slisenko, V.I. (2014). Struktura i dinamika kristallicheskoy reshetki tverdykh rastvorov na osnove dioksida tsirkoniya [Structure and dynamics of the crystal lattice of solid solutions based on zirconium dioxide]. Enhancing the Safety and Efficiency of Nuclear Energy: Sbornik dokladov IV mezhdunarodnoy nauchno-prakticheskoy konferentsi (30 sentyabrya -03 oktyabrya 2014 hoda - Collection of reports of the 4th International Scientific and Practical Conference( September 30-October 03, 2014) (pp. 290-295). Odessa.

Received July 17, 2017

Accepted July 24, 2017 